\title{
A Case for Creative Misunderstanding
}

\begin{abstract}
The differences between us necessitate the dialogue, rather than disallow it - a dialogue must take place, precisely because we don't speak the same language. (Ahmed, 2000, p. 180, italics in the original)
\end{abstract}

Human ways of life increasingly influence, dominate, parody, translate, and subvert one another. (Clifford, 1986, p. 22)

I begin with an admission: I'm not Māori, not indigenous in any place or in any way that would allow me to speak and write with such authority. Nor, for that matter, am I a dancer. I'm an American theatre-trained, performance ethnographer. As a performance ethnographer, everywhere I go, everywhere I look, I see performances, and while I may not understand the language or conventions of the performances I see, even so I tell the story of my seeing performances to others.

This paper explores the position of the spectator/scholar in relation to indigenous performance - in this case, Kapa Haka. While not slighting the problematics of the power dynamic in watching and writing about performances that, lacking language and cultural identifications, I cannot comprehend literally, this paper makes a case for creative misunderstanding. It values the scholarly production of meanings that can be put into play, connecting, challenging, contesting and creating conversations across the cultural divide in ways that may not always be correct but that, in the friction between the two sides of an exchange, might just 
provoke new ways of thinking about, as well as of making, performance in and of culture.

Over the years, I have been increasingly troubled by a trend in Performance Studies toward utopianism, as epitomised by Jill Dolan in her highly influential book Utopia in Performance (2005). Dolan takes an idealist's idealistic stance, arguing for theatrical experiences that are bathed in celebrations of communitas, in which spectators and performers see themselves reflected in a mirror of progressive values, unified and purified - at least for the duration of the performance - of the harsher realities lurking just outside. Selecting performances with which she can directly identify herself - as a 'feminist, or lesbian, or Jew' - Dolan argues that others need not make the same direct identification; in utopian performance, 'being a human being [is] enough' (p. 25).

Touching, isn't it? Tempting too. After decades of identitarian politics and political correctness, of striving, to discover ourselves (hopefully) as one sort of marginalised 'Other' or another and, often failing, to be simply human again. It is a profound desire, expressed by someone who has risen to the top of the academic hierarchy and who is, as such, extraordinarily privileged: to be able to transcend one's social particulars - especially those that might align us with the histories of oppression and colonisation - to partake of acts of dis-identification with the dominant (by implication male, straight, white) culture, to be not-this-but-that . . . at least for the duration of the performance. I can be human. I can be a good person. Utopian indeed.

Dolan is writing about the theatre, picking up where Tim Miller and David Román left off ten years earlier when they valorised the act of 'Preaching to the Converted' (1995). Like Dolan, Miller and Román want to defend productions like Angels in America, the sort of political theatre in the USA that was at the time being accused of creating a reflective circle between performers and spectators that is, temporarily at 
least, closed against the imprecations of outsiders. They argue that their audience is actually diverse in its own way: being gay is only one aspect of identities in which gender, race and class also play significant roles. Queer is the connective thread; being together in being oppressed joins performers and audiences regardless of orientation. The references to 'preaching' and 'choir' are deliberate. Like Dolan, Miller and Román do not shy from piety in claiming that a kind of virtuous humanity is inculcated in those who are part of this performance event. Surrender difference all ye who enter the theatre here, and for the time being at least you won't have to worry about being on the wrong side of the cultural divide.

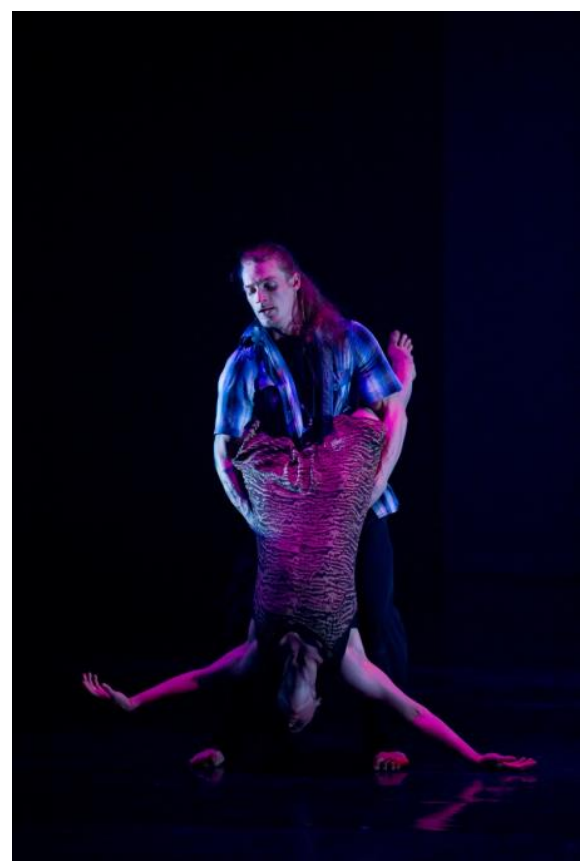

Photo: Stephen A'Court - Tiki Taane Mahuta, by Tanemahuta Gray

Pictured: Jana Castillo and Luke Hanna 
This utopian desire to see oneself as a good person, to identify with the oppressed rather than the oppressor, in the theatre is not limited to performers and audiences. This participatory piety is a kind of plague that has also infected academics as well in ways that I find contradictory and deeply disturbing. Its origins can be traced, in part, I think to Laura Mulvey's feminist theorising, beginning in the early 1970s, about the gaze: the masculine position of the one who looks against the feminised position of the one who is looked at. ${ }^{1}$ If the act of looking itself identifies the one who looks with the dominant culture, the oppressor, then who really wants to go there - especially the scholar whose acts of writing can therefore be seen to collude with the machinery of power, with universities, publishers and politicians?

Underlying the embrace of the utopian is a deep-seated fear of being caught out, to be told 'you just don't understand' because you are not 'one of us' in the communal circle. ${ }^{2}$ Understanding, real understanding, in this construct is only possible if the looker and the looked-at are evenly matched, ideologically speaking. In large part, this fear of hearing you just don't understand' is what has led academics away from critical thinking, speaking and writing toward more expressionistic, diaristic or performative engagements with theatre and dance.

I remember seeing Ann Daly - a first rate scholar of dance and performance art - turn an academic paper about Carolee Schneeman into a kind of shamanistic conjuring: a performance art-esque rendering of the scholar's desire to efface the distance between herself and the object of her research. (This was at an Association for Theatre in Higher Education conference sometime in the 1990s.) At about the same time, at a Modern Language Association conference, with about 10,000 people attending, in New York, I also saw prominent dance scholar, Susan Leigh Foster, dance her paper: stretched arms and legs, intoned odd words . . I'm not sure what that was about, but I still can see her wafting 
around the table and the other panellists. Soon thereafter I started hearing the term 'performative writing' used to describe the sorts of academic performances I was seeing and also to support acts of writing that were self-consciously staged against the dominant grain of scholarship. ${ }^{3}$ Through such performative performances, these feminists were selfconsciously denying identification with the dominant culture, regardless of their cultural status per se. And soon enough they were joined by . . . well . . . by just about everyone in academia wanting to occupy the safety of the margins. ${ }^{4}$

Remember 'saming'? That early 1990s pejorative, first wave PC term for someone seen to be trying to erase the difference between Self and Other? We're well beyond that little bit of ironic self-awareness now. Now both Self and Other must be, reflectively, beyond reproach. The current unwritten rules of contemporary theatre scholarship are such that it is almost impossible to write critically of performance; the performance must be worthy, the article must valorise in some way, and the writer must demonstrate understanding through direct identification with the values represented in the act of writing.

But what happens outside the theatre, on the staging grounds of identity in everyday life? How is Performance Ethnography even possible on such terms? This is not an idle or abstract question. I am an academic whose career has been successfully built on research performed in places where it is screamingly obvious that I don't belong: from the Unpredictable Johnny Rodz School of Professional Wrestling to Te Matatini. I have had my nose rubbed in the improprieties of my watching and writing plenty of times, and - more importantly - I am regularly reminded of my failure to understand what I am watching in terms that can be recognised by those whom I am watching. In fact, I have written about the power dynamics and problematics of Performance Ethnography at regular intervals. In 'Watching Wrestling / Writing Performance' (2002), for example, I 
claimed that regardless of the challenges to my presence in Gleason's Gym, I would always have the last word in publishing my account of the experience. In 'Performance: Ethnographer / Tourist / Cannibal' (2011), I went further in asserting that writing was always already a distinctive practice that should stand, however uneasily, explicitly on its own 'two feet' alongside the performance, and I proposed that 'ethnographers shouldn't dance.' In what remains of this paper, I want first to take a step back through the past decades of discussion about the ethics of ethnography, and then to make my case for creative misunderstanding - indeed to argue that misunderstanding is intrinsic to the ethnographic experience, bound up as it is in the encounter between peoples, and that, as such, virtue should be made of sterner stuff.

In 'Performing as a Moral Act: Ethical Dimensions of the Ethnography of Performance' (1985), Dwight Conquergood justifies his practice of performing ethnography, literally, in creating performances as well as publishing the results of his research in Native American and Southeast Asian immigrant communities. For Conquergood, performance - in particular ethnographic performance - is the enactment of a moral stance' (p. 4). Faced with hostile audience, Conquergood takes this essay as an opportunity to work through his concerns for 'the complex ethical tensions, tacit political commitments, and moral ambiguities inextricably caught up in the act of performing ethnographic materials'; at the same time, however, he insists on 'performance as a way of knowing and deeply sensing the other' (p. 4). It is not, that is, sufficient to watch from the stands or the sidelines. To justify his own performances and provide instruction for those who would follow in his footsteps, he presents a schematic analysis of 'ethical pitfalls, performative stances toward the other that are morally problematic' (p. 4): 'The Custodian's Rip-Off'; 'The Enthusiast's Infatuation'; 'The Skeptic's Cop-Out'; and 'The Curator's Exhibitionism'. These stances are placed on a 
matrix, set between identity and difference on one axis, detachment and commitment on the other, with their distinctive sins listed and the virtuous aim, 'Dialogical Performance' (defined as 'genuine conversation'), at centre. ${ }^{5}$

Conquergood's 'Moral Map' appears somewhat as a flight from 'white guilt', which he simultaneously names and denies. It represents an (almost painfully) earnest attempt to reach what might be termed 'ethnographic safety'. With good reason. There is no safe place. This does not mean that his ideal - 'the dialogical stance [which] is situated in the space between competing ideologies [. . . one that] brings self and other together even while it holds them apart' (p. 9) - is not worth pursuing. He wants to see a 'true respect for the Difference of other cultures' in which 'we grant them the potential for challenging our own culture' (p. 9). Each voice, he says, should have 'its own integrity' (p. 10). True that. It's just that, in the end, his argument turns on his desire not so much to encounter and come to terms with others, or an Other, but to be seen as a moral person:

Dialogical performance is a way of finding the moral center as much as it is an indicator that one is ethically grounded. One does not have to delay entering the conversation until self and other have become old friends. Indeed, as the metaphor makes clear, one cannot build a friendship without beginning a conversation. Dialogical performance is the means as much as the end of honest intercultural understanding. But what are the qualities one absolutely needs before joining the conversation? Three indispensables, according to [Henry] Glassie: energy, imagination, and courage. (p. 10) 
I'm all for 'energy, imagination, and courage.' It's the 'we grant them the potential' that gets to me. Who is this 'we' to be granting - granting! - a 'them' what 'they' already have?

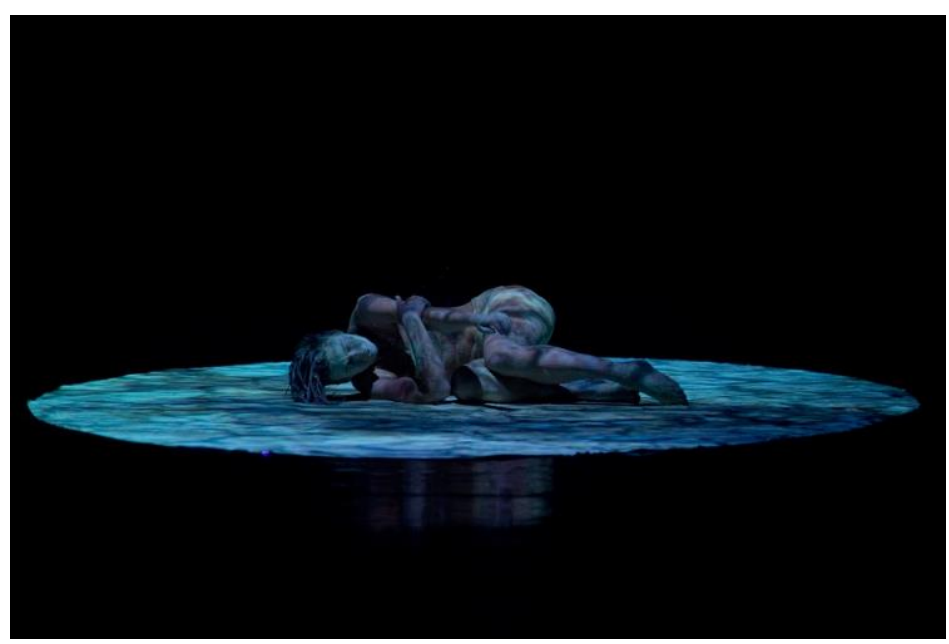

Photo: Stephen A'Court - KIRI by Louise Potiki Bryant

Pictured: Louise Potiki Bryant

Perhaps my disquiet with what sounds a bit great white father-esque to me, stems from the fact that while I started my own work as a performance ethnographer around the time Conquergood was writing this, my first experiences were with professional wrestlers whose ability to challenge my presence ringside was never in question. The sure knowledge that they could defend themselves against my imprecations was not solely founded the obvious differences in physique and temperament. They could speak for themselves, quite eloquently, in at least two languages. They had their explanations for what they were doing, and I had mine. Most didn't care what I had to say, because they were sure they knew better. Sometimes - professional wrestling being, I think, the epitome of dialogic performance - they invited me to play a role - the model spectator, cheering or jeering - or to give 
feedback - 'yes, you're right, that does look really painful' - or just to gossip a bit at the end of the day. One of the more dominant wrestlers was himself a $\mathrm{PhD}$ candidate in sports sociology, whose first major conference paper was an ethnographic study of me doing an ethnographic study of him called 'Sometimes a Bloody Nose is Just a Bloody Nose' (2010). It won him, and me, some notoriety and led to further academic exchanges that were alternately fierce and convivial, and mostly staged for onlookers in order to generate heat of the academic persuasion. At base, though, there was a recognition between us: his line of sight as a wrestler was, in its own way, as limited as mine as a spectator. What mattered, when we quarrelled about the facts and significance of what had happened during a particular event, was the way the ensuing conflict provoked us to think harder, more deeply and more widely about how professional wrestling potentially produces meanings beyond what was obvious to each of us on our own.

It is almost certainly unfair of me to criticise Dwight Conquergood both for his condescension towards his informants and for his denial of his relative power in the relationship regardless. He couldn't help being who he was in that room at that time, any more the rest of us can turn away from our own, individual and collective, acculturations and histories. But like Dolan, twenty years later, his desire to be a good person whilst performing acts of scholarship can be seen in hindsight to have blinded him to the very differences he wanted to discover for himself. After all, how can he - or any of us - find out about an Other without seeing himself - our Selves - for what he is - for what we are - socially as well as morally?

Allow me one more leap backwards in time, before I come to my own 'case'. Conquergood leans heavily on his predecessors in constructing his ethics of ethnography. Above all, from his title to his conclusion, he relies on Clifford Geertz, especially Geertz's essay (1968): 'Thinking as a Moral Act: 
Ethical Dimensions of Anthropological Fieldwork in the New States'. ${ }^{6}$ It is to Geertz that Conquergood turns in the end to define 'ethnographic understanding' as 'more like grasping a proverb, catching an allusion, seeing a joke - or [. . . ] reading a poem - than it is like achieving communion' (p. 11).

Put to one side, for a moment, the underlying assumption that the native ${ }^{7}$ speaks in mysterious ways which are then made understandable via the ethnographer's more authoritative, presumptively intelligible, interpretive act. We'll come back to that soon enough. Let's take a quick look at Geertz. Following in the footsteps of the early $20^{\text {th }}$ century philosopher, and 'revolutionary moralist', John Dewey, Geertz begins his essay with two assertions: (1) that 'thought is conduct and is to be morally judged as such' and (2) that 'the reason thinking is serious is that it is a social act, and that one is therefore responsible for it as for any other social act' (1968, p. 139). Sounds like a close ancestor of late $20^{\text {th }}$ century Political Correctness, this channelling of early American Puritan propriety through the social conscience of the 1960s cultural anthropologist, does it not?

But thinking of ethnographic thinking as a social act should provoke us to see ourselves as actors in the social drama. Seeing ourselves as actors should open us to interrogation on a fundamental level: who am I; what are my given circumstances; what is my social status; what do I want; what strategies are available to me in pursuing my objectives and what do I gain or lose in so doing? Above all, as an actor I know I have to discover what comes to me in the course of acting, including finding out in more tangible terms who the other actors are their circumstances, social realities, objectives, etc. ${ }^{8}$ However, even though Geertz, writing in 1968 , recognises that he is acted upon as well as acting, looked at as well as looking, what he doesn't fully see is that it's not a level playing field. He encounters his 'informant' from a position of unthinking superiority, and his conclusion is that . . well . . . much as he'd like to, he just doesn't understand. ${ }^{9}$ 
Of course, recognising that there are limits to his ability to understand is not the end for Geertz. His essays 'Thick Description: Toward an Interpretive Theory of Culture' and 'Deep Play: Notes on the Balinese Cockfight' (1973) can be read as cornerstones of Performance Studies, as well as of anthropology and ethnography. In these essays, Geertz stages himself as both a player and an artist: directly engaged on a daily basis with the natives in whose village he has pitched his tent and as such, taking his cues from them, created his own narrative within which he seeks to capture something essential about the culture into which he has stumbled. That is, the anthropologist tells the story of his encounter with the natives, knowing that it's at least as much his story and not precisely theirs that he's telling, and - in the early 1970s at least - he is not necessarily expecting to be corrected. He's not careless in this telling. In fact, he is rather meticulous in marshalling the details of his observations, but still, through this story he seeks to make visible the Others and their culture in a meaningful way. The native winks at him, and in trying to make sense of that wink he discovers an entire world view.

In his interpretation of the Balinese cockfight, Geertz misunderstands almost everything about the Balinese and their culture. There are puns that undermine rather than support meaningful engagement - the most egregious, of course, attached to the word 'cock'. There are gaps and elisions, remarkable blind spots that have been pointed out in the decades since, errors that go beyond worrying about his attitude toward the Balinese villagers; for example, only late in the narrative does he mention his wife who seems to have been with him all along and is not even named in Geertz's thick description. But in his misunderstanding he creates a compelling narrative about encounter in which, as a selfconscious actor in a social drama, he deliberately steps away from the high ground of academic authority and makes himself available also for critical analysis. Fast forward now 
about twenty years, to the early 1990s, and we can find a whole slew of ethnographers - among them, Renato Rosaldo, Vincent Crapanzano, Mary Louise Pratt, James Clifford and George Marcus - taking Geertz's theory and practice to task for what is now obvious: natives have eyes too, along with the wherewithal to construct their own narratives of encounter. ${ }^{10}$

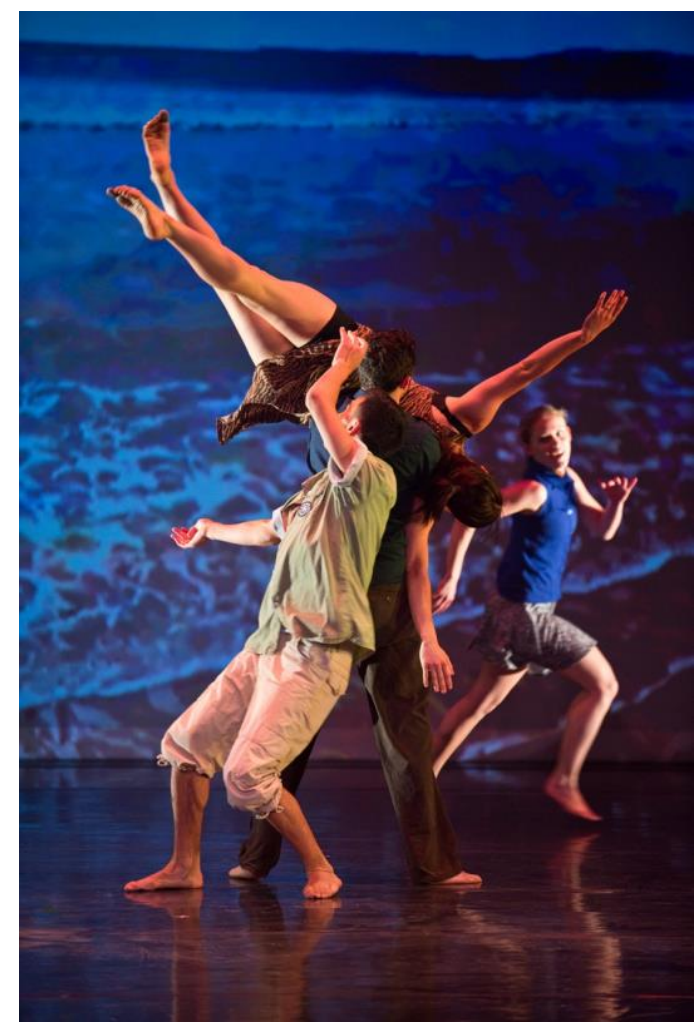

Photo: Stephen A'Court - Tiki Taane Mahuta, by Tanemahuta Gray

Pictured: Jana Castillo, AnitaHunziker, Mark Bonnington and Sharn Te Pou 
As James Clifford notes in his Introduction to Writing Culture: The Poetics and Politics of Ethnography (1986): "The making of ethnography is artisanal, tied to the worldly work of writing' (p. 6). Clifford goes on to say: 'Even the best ethnography texts - serious, true fictions - are systems, or economies, or truth. Power and history work through them, in ways their authors cannot fully control' (p. 7). He sees the ethnographer as 'a character in a fiction [. . .] at center stage' (p. 14). As idealistic in his own way as his contemporary, Dwight Conquergood, Clifford tells us that the point is now 'to dislodge the ground from which persons and groups securely represent others.' He says:

A conceptual shift, "tectonic" in its implications, has taken place. We ground things, now, on a moving earth. There is no longer any place of overview (mountaintop) from which to map human ways of life, no Archimedian point from which to represent the world. Mountains are in constant motion. So are islands: for one cannot occupy, unambiguously, a bounded cultural world from which to journey out and analyze other cultures. Human ways of life increasingly influence, dominate, parody, translate, and subvert one another. Cultural analysis is always enmeshed in global movements of difference and power. However one defines it [. . .] a "world system" now links the planet's societies in a common historical practice. (p. 22, emphasis mine)

This doesn't mean we're now all the same. Or that the asymmetries of power and status have been, or ever can be, equalised. We speak, write and act ourselves into meaningful relationships with one another. Ideally we do so in ways that 
are both self- and other-aware. Utopia? No. And pretending otherwise won't make it so.

And yet. That we can't be good people and do ethnography at the same time, that we can't convincingly perform such piety, doesn't mean we shouldn't do it. Or that we should tie ourselves up in apologetic knots in hopes of offsetting the power dynamics involved when crossing the cultural divide.

As talkative and inclined to interrupt as I am, I like the way a hui works. Performance ethnography should be a form of utu within the framework of a shared, or at least intersecting, kaupapa: The writer sets out his/her position in a mihi of sorts, beginning with whakapapa and tūrangawaewae: who he or she is - who $I$ am - in relation to everyone here, how I come to be in this or that room watching this performance, what I saw and what I make of it now, talking to all of you. In writing, I put my figurative cards on the table where everyone can see them; in speaking I stand up for myself, say what I'm thinking and take what comes back to me. I am also forced to recognise that, even in performance and even more in cultural performance, in Māori performance, not everything can or should be seen, or understood. That's ok by me. It's enough to be in the room, as it were. I am not owed transparency, explanation or correction. What I want is a conversation, a dialog where I can hear the other side on its own terms and meet it on mine.

So for example, in several articles I have argued that the performance of Kapa Haka as a staging of recognition and resistance set against the constraints of colonisation represented by the proscenium arch. In response, I have been told that this effect is accidental and secondary to the display and celebration of virtuosity in reo and tikanga. Where I see an indigenous confrontation with the (not-quite absent) European - that is, a theatricalisation of the tension between the colonised and the coloniser - performers, spectators and kaumatua say the point is the conversation amongst themselves and, as such, largely beyond me, because of my 
very limited grasp of the reo and my coming so late to the culture. ${ }^{11}$ Fair enough. At the same time, my observations are useful, I'm told, because they come from the outside, provoking my correspondents to counter authoritatively, to affirm their deeper understandings and produce the kinds of scholarly arguments that I cannot. Regardless, the field is growing rapidly. When I started writing about Māori performance there was little in English (or even in te reo I'm told) of a scholarly persuasion. Now my voice is one of many. ${ }^{12}$ You can decide for yourself what it's worth.

I am not Māori. I am not a dancer. I see what I see from the outside. I miss a lot, misunderstand much, and yes, consciously and unconsciously in my writing about Māori performance, I do a fair bit of making it up as I go along. Writing, for me, is a creative act, a performance, my own little wordy dance, and while I often stand corrected, I have certainly gained mana internationally for my interpretations of Māori performance and culture. At best - and here I admit to my own idealism - my publications provoke publications in response. At best they serve as the foundation for a conversation, multiple conversations; some of these might even include me. It's not a question of being a good or bad person, or being right or wrong per se. These values don't disappear, but they sit fairly far apart on a continuum, a series of intersecting matrices, really. In the best of all possible worlds, I'm not going to understand much of anything fully. That's why I keep looking. 


\section{REFERENCES}

Ahmed, S. (2000). Strange encounters: embodied others in postcoloniality. London \& New York: Routledge.

Browning, T. (1932). Freaks. MGM.

Cleave, P. (2014). Memory, body and dance: a review of literature. Te Kaharoa 7(1), 25-61. http://www.tekaharoa.com/index.php/tekaharoa/article/view/1 $\underline{67 / 125}$.

Clifford, J. (1986). Introduction: partial truths. In J. Clifford \& G. Marcus (Eds.), Writing culture: the poetics and politics of ethnography (pp. 1-26). Berkeley \& Los Angeles: University of California Press.

Clifford, J. (1997). Routes: travel and translation in the late twentieth century. Cambridge, MA \& London: Harvard University Press.

Conquergood, D. (1985). Performing as a moral act: ethical dimensions of the ethnography of performance. Literature in Performance, 5(2), 1-13.

Crapanzano, V. (1992). Hermes' dilemma and Hamlet's desire: on the epistemology of interpretation. Cambridge: Harvard University Press.

de Garis, L. (2010). Sometimes a bloody nose is just a bloody nose: play and contest in boxing, wrestling, and ethnography. Sport and Society: Cultures, Commerce, Media, Politics, 13(6), 935-951.

Dolan, J. (2005). Utopia in performance: finding hope in the theatre. University of Michigan Press.

Douglas, M. (1982). Cultural bias. In the active voice (pp. 183-254). London: Routledge.

Geertz, C. (1968). Thinking as a moral act: ethical dimensions of anthropological fieldwork in the new states. The Antioch Review, 28(2), 139-158.

Geertz, C. (1973). Interpretation of cultures: selected essays. New York: Basic Books.

Geertz, C. (1974). 'From the native's point of view': on the nature of anthropological understanding. Bulletin of the American Academy of Arts and Sciences, 28(1), 26-45.

Geertz, C. (1983). Local knowledge: further essays in interpretive anthropology. New York: Basic Books.

Hagen, U. (1973). Respect for acting. New York: Macmillan.

Ka'ai, R., Ka'ai, T., \& Moorfield, J. (2013). Kia Rōnaki: the Māori Performing Arts. Auckland: Pearson.

Mazer, S. (2002). Watching wrestling / writing performance. In H. Jenkins III, T. McPherson, \& J. Shattuck (Eds.), Hop on pop: the politics and pleasures of popular culture (pp. 270-286). Durham, NC: Duke University Press.

Mazer, S. (2011). Performance: Ethnographer / Tourist / Cannibal. Australasian Drama Studies, 59, 104-120.

Miller, T. \& Román, D. (1995). "Preaching to the converted". Theatre Journal, 47(2), 169-188. 
Mulvey, L. (1989). Visual pleasure and narrative cinema. Visual and other pleasures (pp. 14-30). Houndmills, Basingstoke, Hampshire: Macmillan.

Phelan, P. (1998). Introduction: the ends of performance. In P. Phelan \& J. Lane (Eds.), The ends of performance (pp. 1-22). New York \& London: NYU Press.

Pratt, Mary Louise. (1992). Imperial eyes: travel writing and transculturation. London \& New York: Routledge.

Rosaldo, R. (1989). Culture and truth: the remaking of social analysis. Boston: Beacon Press.

Schechner, R. (2012). Occupy Solidarity. TDR: The Drama Review, 56(1), 7-9.

Tannen, D. (1990). You just don't understand: men and women in conversation. London: Virago.

1 Mulvey's wildly influential essay 'Visual Pleasure and Narrative Cinema' was written in 1973 and first published in Screen in 1975. By the time it was republished (in her first essay collection, Visual and other Pleasures,1989) Mulvey was re-thinking her original insights, but although the political terrain has shifted many times since, for me they still hold substantial truths about the ways we experience and frame the acts of looking and being looked at.

2 The reference to Freaks and the ambivalent refrain 'one of us' chanted during the pivotal scene of the wedding between Hans (the 'freak') and Cleopatra (the 'norm') - is intentional.

3 See, for example, the way Peggy Phelan reifies 'performative writing' as an academic practice in her introduction to The Ends of Performance (1998).

4 Even Richard Schechner, founder of Performance Studies and University Professor at NYU, has made a practice for many years of such identifications, most recently identifying himself with the $99 \%$ in a TDR editorial standing with his students at the Occupy Wall Street protest ('Occupy Solidarity', 2012).

5 Conquergood cites Mary Douglas as a model, in particular, for her method for 'grid/group analysis' as discussed in 'Cultural Bias' (1982).

6 Conquergood cites a number of texts by Geertz, including 'From the Native's Point of View': On the Nature of Anthropological Understanding (1974) and Local Knowledge: Further Essays in Interpretive Anthropology (1983). Oddly, however, Interpretation of Cultures (1973), which is the root of much of what we know of Performance Studies, is not directly referenced; even so, its essence permeates Conquergood's essay, especially in the essay's concluding paragraphs.

7 Please note that I am using the word 'native' intentionally, introducing it into this paper when I turn to Geertz, because it is of its time, and as much for its less than politically correct 
connotations as because as such it is a word deeply implicated in the ethnographic endeavour.

8 See Uta Hagen's Respect for Acting, which is grounded in large part on the principle that an actor takes responsibility for her character's actions and acting as the character discovers the other actors-as-characters only in action, through the interactions of the performance as it unfolds, fresh each time.

9 In this, of course, I am intentionally echoing Deborah Tannen's influential book You Just Don't Understand, which takes a linguistic approach to the war between the sexes.

10 For example, James Clifford begins Routes: travel and translation in the late twentieth century (1997) by rejecting the notion of the native village, and the natives within, as being fixed in place and time. Rather, following Amitav Ghosh, he picks up the image of the 'traditional, rural village as airline transit lounge' (p. 1) as the starting point for reconsidering ethnographic practice as increasingly dialogic and multi-valent.

11 See Peter Cleave's elaboration and contextualisation of my work on Kapa Haka, which is itself the product of an extended conversation, in 'Memory, body and dance: a review of literature' (2014).

12 See, for example, Kia Rōnaki: The Mãori Performing Arts, edited by Rachael Ka'ai-Mahuta, Tania Ka'ai and John Moorfield (2013). 